\title{
The Financial Risk Evaluation in Turkish Banking System
}

\author{
Asst. Prof. Dr. Semin Paksoy (Çukurova University, Turkey) \\ Ph.D. Candidate Mehmet Fatih Traş (Çukurova University, Turkey)
}

\begin{abstract}
Banking activities exhibit highly dynamic and evolving feature in recent years. Healthy financial position of the banks therefore gains importance in assuring well being of all economic agents in a country. Because of banks' key role in financial markets and real economy, banking failures or inefficient performances may have profound effects on the whole economy. For this reason, it is important to monitor the bank ratios as a strength indicator. Therefore, this paper aims to investigate financial position of the banks in Turkey. To this end, we select particular 29 ratios of the present day banks which are matching the ratios of previously failed banks between the periods 1997-2003. Therefore, we construct a data set by which the banks can be categorized into two groups, namely failed and non-failed banks. Data covering the period 1996-2014 extracted from Banking Regulation and Supervision Agency.

In the first place, we perform ANOVA test to evaluate the most relevant ratios for bank failure. The ANOVA test results reveal that 13 of 29 ratios are not significant. The remaining ratios are used to implement factor analysis in order to categorize ratios and calculate factor scores. Lastly, we estimate a Probit regression model to determine conditional probability of failure for a given bank. Our results show that financial position of the banks exhibits substantial variations in Turkey. Furthermore, given the data set and methods employed, most of the banks have a robust financial position and are unlikely to fail.
\end{abstract}

\section{Introduction}

Nowadays, financial markets are closely linked to each other in the world and therefore the economic crisis occurring in a country can be detected by any other country and can trigger other financial markets in very fast and quick way. Some authors, such as Honohan and Klingebiel (2003) have studied to explain the causes of the crisis and how it spread. Their analysis has concluded that some factors of the global crises are familiar with the past crisis while the others are not. A major common feature of the banking crisis is the higher fiscal costs arising from boosting programs, using public funds. Some other authors have introduced that governments' outlays for support programs have been about $12.8 \%$ of national GDP to cover the losses. In developing countries, these expenses have reached to $14.3 \%$ of GDP. The extreme percentage in their detailed investigation of crisis history is highlighted as 40-55\% of GDP in early 1980s crises in Argentina and Chile (Caprio and Klingebiel, 2002).

Banks, having the important place in the financial market is directly affected from the crisis of today's integrated market. The greatest bank failures occurred in Turkey during the period 1997-2003. During this period, 22 of Turkish banks failed because of the great effects of the outsourcing crisis such as 1997 Asian financial crisis, 1998 Russian financial crisis and 2001 financial crisis. Although the later crisis, such as 2008 global financial crisis have also affected the Turkish economy, there has not been announced any bankruptcy. Many critics argue that Turkey has the ability to withstand the economic crises due to implementing necessary legal and institutional reforms following the liberalization of the Turkish economy in the early 1980's. As a matter of fact, Turkey has been transforming into a market economy since the $1970 \mathrm{~s}$. However, a certain degree of government intervention still existed within the economy. This intervention came in the form of the government's influence over the Central Bank's decisions and its ownership of banks (Chen et.al. 2014) since private depts have come public depts after the crisis (Reinhart and Rogoff, 2010).

Of course, government intervention in terms of support programs have been put regulations into practice to prevent effects of crisis or to restore and enforce banks' performances. These programs include various types of resolution policies; mergers of banks, sales to local/ foreign investments or recapitalization. The cost of support programs have led to displeasure among the taxpayers and economists since there is no optimal resolution mechanism of banking crisis (Contessi and El-Ghazaly, 2011). Therefore it is the most important to analyze and monitor the performance of banks regularly. Monitoring the performance and especially taking necessary steps toward the success have provided the ability in forestalling future crises.

In the literature, several recent studies have investigated various parameters of banking crisis. Papi et.al (2015) has discussed triggers of banking crises considering three indexes of the countries. They are the index of country risk which is for political, financial and economic riskiness, the index of access to sound money which measures the growth rates of money supply and inflation, and the freedom to own foreign currency bank accounts domestically and abroad, and the polity score which ranks governing institutions from autocratic to democratic. Their results show that the access to sound money is an element which mitigates the vulnerability of the banking system to systemic crises.

Reinhart and Rogoff (2011) have investigated what constitutes of a financial crisis and which methods can be used to determine the date of beginning and the end the possible crises, depending on the historical huge data. 
Further, the probability of banking crisis does not differ significantly according to the institutional and policy setup and to the institutionalized democratic regime. On the other side, Claessens et.al (2005) introduced that crisis management policies can affect the magnitude and cost of the crisis. Similarly, Honohan and Klingebiel (2003) introduced that financially strong banks will probably have lower intervention and thereby efficient crisis management have led to lower fiscal cost in the presence of crises.

This paper has two purposes. In the first place, we investigate the financial conditions of the banks operating in Turkey since the period 2001-2003 where a large number of bankrupts were witnessed. Secondly, we aim to scrutinize whether banks were affected by 2008 financial crisis.

The reminder of this study is organized as follows. In the second chapter we summary the methodology and data used. In the third chapter we present our empirical findings, and in the fourth chapter, we conclude.

\section{Methodology}

\subsection{The Sample and Variable Selection}

The sample set of the study covers financial ratios of Turkish deposit banks for the periods 1996-2014 with the exception of 2001 since Turkey was of economic and financial crises in 2001 in which ratios are not published.

There are 49 deposit banks in this study. Twenty-seven of them are current banks three of which are state-owned deposit banks, eleven of which are privately owned banks and thirteen of which are foreign banks entering the Turkish banking sector. In the periods 1996-2003, 22 of 49 deposit banks that were takeover by the Savings Deposit Insurance Fund of Turkey are classified as failed banks, while remaining banks, operating in banking sector after the 2003 are classified as non failed banks. When the whole data is considered for the specified periods 19962014 , failure or non failure state of each bank is described to categorize them into two classes. The failure state is organized as 1 to represent the failure of the banks in one category and as 0 as to represent the other category which is non failure. Failed banks, listed in Table 2 are described according to the declaration of bankruptcy year; one year earlier, two year earlier and three year earlier from the bankruptcy year The failure states for other years of failed banks' and other banks' are organized as 0 to be considered non failed. The system used in the categorization of banks is based on the study of Canbaş et. al.(2005).

\begin{tabular}{|c|c|c|c|}
\hline No & Failed Banks & $\begin{array}{l}\text { Date of Transferred } \\
\text { Funds }\end{array}$ & $\begin{array}{l}\text { Selected Years for Failure } \\
\text { State }\end{array}$ \\
\hline 1 & Türk Ticaret Bankası A.Ş. & November 1997 & 1996,1997 \\
\hline 2 & Bank Ekspres A.Ş & December 1998 & 1997, 1998 \\
\hline 3 & Interbank & January 1999 & $1996,1997,1998,1999$ \\
\hline 4 & Sümerbank A.Ş & December 1999 & $1996,1997,1998,1999$ \\
\hline 5 & $\begin{array}{l}\text { Tütüncüler Failed Banks Bankası } \\
\text { Yaşarbank A.Ş. }\end{array}$ & December 1999 & $1996,1997,1998,1999$ \\
\hline 6 & Yurt Ticaret ve Kredi Bankası A.Ş. & December 1999 & $1996,1997,1998,1999$ \\
\hline 7 & Egebank A.Ş. & December 1999 & $1996,1997,1998,1999$ \\
\hline 8 & Eskişehir Bankası T.A.Ş. & December 1999 & $1996,1997,1998,1999$ \\
\hline 9 & Bank Kapital Türk A.Ş & October 2000 & $1997,1998,1999,2000$ \\
\hline 10 & Etibank A.Ş. & October 2000 & $1997,1998,1999,2000$ \\
\hline 11 & Demirbank T.A.Ş. & December 2000 & $1997,1998,1999,2000$ \\
\hline 12 & Ulusal Bank & February 2001 & $1998,1999,2000^{*}$ \\
\hline 13 & İktisat Bankası T.A.Ş. & March 2001 & $1998,1999,2000^{*}$ \\
\hline 14 & Bayındırbank A.Ş & July 2001 & $1998,1999,2000^{*}$ \\
\hline 15 & Ege Giyim Sanayicileri Bankası A.Ş. & July 2001 & $1998,1999,2000^{*}$ \\
\hline 16 & Kentbank A.Ş. & July 2001 & $1998,1999,2000^{*}$ \\
\hline 17 & Sitebank A.Ş & July 2001 & $1998,1999,2000^{*}$ \\
\hline 18 & Milli Aydın Bankası T.A.Ş. & July 2001 & $1998,1999,2000^{*}$ \\
\hline 19 & Emlakbank & July 2001 & $1998,1999,2000^{*}$ \\
\hline 20 & Toprakbank A.Ş & November 2001 & $1998,1999,2000^{*}$ \\
\hline 21 & Pamukbank T.A.Ş & June 2002 & $1999,2000,2002 *$ \\
\hline 22 & Türkiye İmar Bankası T.A.Ş. & July 2003 & $1999,2000,2002 *$ \\
\hline
\end{tabular}

Selected years are with the exclusion of 2001 since there is missing values for common ratios. Source: Lopcu and K1lıç, 2012 
The number of published financial ratios for the banks operating in the Turkish banking sector, during the period 1996-2000 is only 49 (K1lıç,2006) while there are presently 66 ratios. Among them, only 29 ratios of Turkish deposit banks are common for comparison. Selected ratios for this study are listed in Table 2 . All the branch and activity ratios in current TL are converted to new Turkish Lira (TRY). Furthermore, all monetary variables are expressed in real terms using 2003 based producer price index (PPI).

\begin{tabular}{|c|c|c|c|}
\hline Code & Ratio Categories and Names & Code & Ratio Categories and Names \\
\hline & Assets Quality, \% & $\mathrm{R} 15$ & Total Loans \\
\hline R1 & \multirow{3}{*}{$\begin{array}{l}\text { Total Loans/Total Assets } \\
\text { Non Performing Loans/Total Loans } \\
\text { Permanent Assets/Total Assets }\end{array}$} & $\mathrm{R} 16$ & Total Deposits \\
\hline $\mathrm{R} 2$ & & & Share in Group, \% \\
\hline \multirow[t]{2}{*}{$\mathrm{R} 3$} & & R17 & Total Assets \\
\hline & Liquidity, \% & $\mathrm{R} 18$ & Total Loans \\
\hline R4 & \multirow{3}{*}{$\begin{array}{l}\text { Liquid Assets/Total Assets } \\
\text { Liq.Assets/(Deposits+Non-deposit Funds) } \\
\text { Foreign Ex.Liq.Assets/ForeignEx.Liabilities }\end{array}$} & R19 & Total Deposits \\
\hline R5 & & & Branch Ratios, Million TRY* \\
\hline \multirow[t]{2}{*}{ R6 } & & R20 & Total Assets / No. of Branches \\
\hline & Profitability, $\%$ & $\mathrm{R} 21$ & Total Deposits / No. of Branches \\
\hline R7 & Net Income(Loss)/Average T.Assets & $\mathrm{R} 22$ & TL Deposits / No. of Branches \\
\hline R8 & Net Income(Loss)/Shareholder's Equity & $\mathrm{R} 23$ & Fx Deposits / No. of Branches \\
\hline \multirow[t]{2}{*}{ R9 } & Income Before Tax / Average Total Assets & $\mathrm{R} 24$ & No. of Personnel / No. of Branches \\
\hline & Income-Expenditure Structure, \% & $\mathrm{R} 25$ & Total Loans / No. of Branches \\
\hline R10 & Interest Income/ Total Income & $\mathrm{R} 26$ & $\begin{array}{l}\text { Net Income / No. of Branches Activity } \\
\text { Ratios }\end{array}$ \\
\hline R11 & Interest Income/Interest Expenses & $\mathrm{R} 27$ & $\begin{array}{l}\text { (Salary and Emp'ee Bene. }+ \text { Res. for } \\
\text { Retire.)/No.of Pers.(Billion TL**) }\end{array}$ \\
\hline $\mathrm{R} 12$ & Non-Interest Income/Non-Interest Expenses & $\mathrm{R} 28$ & $\begin{array}{l}\text { Reserve for Seniority } \text { Pay/No.of } \\
\text { Personnel (Billion TL) }\end{array}$ \\
\hline \multirow[t]{2}{*}{$\mathrm{R} 13$} & Total Income/Total Expenditure & R29 & $\begin{array}{l}\text { (Salaries and Emp'ee Benefits }+ \\
\text { Reserve for Retirement)/T.Assets }\end{array}$ \\
\hline & Share in Sector, \% & & \\
\hline R14 & Total Assets & & \\
\hline
\end{tabular}

Table 2. Ratios

\subsection{Probit Model}

A probit model is a type of regression where the dependent variable can only take two values such as bank failure or non failure, and thereby, the probit model is a type of binary classification model. The purpose of the model for binary response variable is to estimate the probability that an observation with particular characteristics will fall into a specific one of the categories. This is reasonable to assume that there is a threshold level. The estimated probabilities greater than 0,5 are treated as classifying an observation into a predicted category.

The main assumption of the binary Probit regression model is that the response function $Y_{i}$ must be in the form of linear regression functions as following equations (1) and (2),

$$
\begin{array}{cl}
Y_{i}=\alpha+\beta X_{i}+\varepsilon_{i} & \\
\text { If } \alpha+\beta X_{i}+\varepsilon_{i}>0, & Y_{i}=1 \text { means bank failure occurs } \\
\text { Otherwise, } & Y_{i}=0 \text { means non failure }
\end{array}
$$

and $Y_{i}$ follows the Bernoulli probability distribution. The use of the least-squares estimator in linear regression in equation (1) is justified by the Gauss-Markov theorem, which does not assume that the distribution is normal. According to the Gauss-Markov theorem, the errors, in a linear regression model have expectation zero and are uncorrelated and have equal variances. The errors $\varepsilon_{i}$ do not need to be normal, nor do they need to be independent and identically distributed. $\varepsilon_{i}$ is also take two values, like $Y_{i}$ (Gujarati, 2003). However, from the perspective of generalized linear models, it is useful to suppose that the distribution function is the normal distribution with constant variance and the link function is the identity, which is the canonical link if the variance is known. Probit model, which employs a probit link function, is most often estimated using the standard maximum likelihood procedure.

The estimating model that emerges from normal cumulative distribution function (CDF) can known as probit model and can be used for the link since the CDF's range is $[0,1]$. $\Phi$ is inverse of the normal CDF $F_{x}: R \rightarrow[0,1]$ of a random variable $\mathrm{x}$ and named as quantile function. CDF $F_{x}$ gives the $\mathrm{p}$ value as a function independent value 
$\mathrm{x}$. The quantile function $\Phi$ in equations (3) and (4) does the opposite, and returns a threshold (minimum) value of $\mathrm{p}$ from among the all values whose CDF exceeds probability $\mathrm{p}$.

$$
\begin{aligned}
& \Phi=\mathrm{F}^{-1} \\
& \Phi(\mathrm{p})=\inf \{x \in R: p \leq F(x)\}
\end{aligned}
$$

In the equation (4), the inf (infimum) function can be replaced by the minimum function. The function $\Phi$ is a popular choice and yields the probit model. For the binary response data $Y_{i}$, the distribution function is generally chosen to be the Bernoulli distribution and the probability, $p$, of $Y_{i}$ taking on the value one. So, for the normal standard variable $\mathrm{z}, \Phi(\mathrm{z})$ is standardized normal CDF and $\Phi(\mathrm{z})=\mathrm{P}(\mathrm{Z} \leq \mathrm{z})$. Then utility index I and threshold of the utility index $I^{*}$ is computed in equation (5). The probability of $I_{i}^{*}$ is less than or equal to $I_{i}$ can be computed from the inverse of the standardized normal CDF $\Phi$ using following equations (6) and (7) (Gujarati, 2003).

$$
\begin{aligned}
& \mathrm{I}_{\mathrm{i}}=\alpha+\beta \mathrm{X}_{\mathrm{i}}+\varepsilon_{i} \text { and } \mathrm{I}_{\mathrm{i}}^{*}=0,5 \\
& P_{i}=\mathrm{P}\left(\mathrm{Y}_{\mathrm{i}}=1 \mid \mathrm{X}\right)=\mathrm{P}\left(\mathrm{I}_{\mathrm{i}}^{*} \leq \mathrm{I}_{\mathrm{i}}\right)=\mathrm{P}\left(\mathrm{Z}_{\mathrm{i}} \leq \alpha+\beta \mathrm{X}_{\mathrm{i}}+\varepsilon_{i}\right)=\Phi\left(\alpha+\beta \mathrm{X}_{\mathrm{i}}+\varepsilon_{i}\right) \\
& P_{i}=\mathrm{P}\left(\mathrm{Y}_{\mathrm{i}}=0 \mid \mathrm{X}\right)=\mathrm{P}\left(\mathrm{I}_{\mathrm{i}}^{*}>\mathrm{I}_{\mathrm{i}}\right)=\mathrm{P}\left(\mathrm{Z}_{\mathrm{i}}>\alpha+\beta \mathrm{X}_{\mathrm{i}}+\varepsilon_{i}\right)=\Phi\left(\alpha+\beta \mathrm{X}_{\mathrm{i}}+\varepsilon_{i}\right)
\end{aligned}
$$

In equation (6), $Y_{i}=1$ represents the bank failure since $I_{i}$ exceeds the threshold $I_{i}^{*}$. Similarly, in equation (7), $Y_{i}=0$ represents the non failure of the bank which occurs when a bank is unable to meet the obligation which is exceeding the threshold level.

\section{Empirical Results}

To evaluate the financial risk in Turkish banking system, we start have started with identifying the most decisive bank ratios for which significant differences across failed and non-failed banks exist. For this reason, we employ ANOVA test. In ANOVA test we use significance level as $1 \%$ to conclude on statistically significant differences. Because there are missing variables on 55 observations in the data set, we perform the analysis using different approaches to overcome this problem. In the first place we ignore the missing data and obtain results accordingly. In the second approach, we replace the missing data with the mean of the corresponding variable. Not least, we carry out the same methodology by replacing the missing data with nearby points. Because in ANOVA and Factor Analysis there are no major differences in the results for the three missing data replacing methods, we mainly present the result of ANOVA and Factor Analysis in the case where missing values are present in the data set. ANOVA test results are given in Table 3.

\begin{tabular}{rrrc}
\hline Ratio & Mean Square & F & Sig. \\
\hline R1 & 2808,09 & 7,25 & $0,01^{*}$ \\
R2 & 147290,95 & 1,28 & 0,26 \\
R3 & 1693,46 & 25,39 & $0,00^{*}$ \\
R4 & 1463,87 & 3,95 & 0,05 \\
R5 & 62981,97 & 3,49 & 0,06 \\
R6 & 10725,03 & 6,59 & $0,01^{*}$ \\
R7 & 19350,19 & 66,99 & $0,00^{*}$ \\
R8 & 94102,62 & 1,42 & 0,23 \\
R9 & 20136,39 & 66,54 & $0,00^{*}$ \\
R10 & 20650,82 & 2,15 & 0,14 \\
R11 & 444405303,99 & 0,19 & 0,66 \\
R12 & 348341,37 & 39,18 & $0,00^{*}$ \\
R13 & 8915,01 & 6,57 & $0,01^{*}$ \\
R14 & 242,93 & 14,02 & $0,00^{*}$ \\
R15 & 209,60 & 13,72 & $0,00^{*}$ \\
R16 & 228,27 & 11,14 & $0,00^{*}$ \\
R17 & 524,34 & 7,71 & $0,01^{*}$ \\
R18 & 1703,75 & 15,47 & $0,00^{*}$ \\
R19 & 357,55 & 4,89 & 0,03 \\
R20 & 135513,88 & 3,50 & 0,06 \\
R21 & 10286,14 & 1,06 & 0,30 \\
R22 & 1624,48 & 1,05 & 0,30 \\
R23 & 3735,13 & 0,85 & 0,36 \\
R24 & 2736,46 & 0,80 & 0,37 \\
R25 & 19522,77 & 5,76 & 0,02 \\
R26 & 2958,03 & 25,96 & $0,00^{*}$ \\
R27 & 62367,84 & 50,45 & $0,00^{*}$ \\
R28 & 18,61 & 17,53 & $0,00^{*}$ \\
R29 & 43,96 & 14,73 & $0,00^{*}$ \\
\hline
\end{tabular}

* Statistically significant ratios 
Our results show that 13 of 29 bank ratios indicate statistically significant differences at $1 \%$ level. These ratios are R1, R3, R6, R7, R9, R12-R18 and R26-R29. The ratios which do not show a significant difference are omitted from the data set.

As the second tool of our empirical strategy, we use factor analysis to group the ratios exhibiting similar characteristics and therefore to reduce the number of variables used in the analysis. In factor analysis the correlation assumption must be controlled. For this purpose we use Kaiser-Meyer-Olkin (KMO) and Bartlett's test. The null hypothesis of Bartlett's test states that variables used in the analysis are orthogonal, that is, the variables are not correlated sufficiently to be used in factor analysis. On the other hand, for an efficient factor analysis results, KMO index is required to be close to 1. (REFERENCE for KMO LIMITS) Our KMO and Bartlett's test results are given in Table 4. KMO index for the data sets where missing values are replaced with mean and nearby points are 0,649 and 0,647, respectively. For both cases in Bartlett's Test we cannot reject the null hypothesis with $99 \%$ confidence level.

\begin{tabular}{l|l|l}
\hline Kaiser-Meyer-Olkin Measure of Sampling Adequacy. & & 0,648 \\
Bartlett's Test of Sphericity & Approx. Chi-Square & 9123,449 \\
& df & 120 \\
& Sig. & 0,00 \\
\hline
\end{tabular}

Table 4. KMO Index and Bartlett's Test Results

According to Table 4, KMO index is sufficiently close to 1 . On the other hand, Bartlett's test results show that we can reject the null of orthogonality among variables at $1 \%$ significance level. These results confirm that our data set is suitable to perform factor analysis. In the factor analysis, we use Varimax for rotation method and use regression to compute the corresponding factor scores. Furthermore, we use the eigenvalue of 1 as the limit to determine the number of factors. Table 5 presents the result of factor analysis. Results show that bank ratios can be classified within four factors. Besides, these four factors can explain $66,34 \%$ variance of total variance. According to the result the factor which explains the total variance most is factor 1 with $25,62 \%$. This factor is followed by factor 2 , which can explain $19,29 \% .44,91 \%$ of the total variance can be explained by these two factors.

\begin{tabular}{llll}
\hline \multicolumn{4}{l}{ Initial Eigenvalues } \\
\hline Component & Total & \% of Variance & Cumulative \% \\
\hline 1 & 4,10 & 25,62 & 25,62 \\
2 & 3,09 & 19,29 & 44,91 \\
3 & 1,80 & 11,27 & 56,19 \\
4 & 1,62 & 10,15 & 66,34 \\
5 & 0,98 & 6,13 & 72,47 \\
6 & 0,87 & 5,42 & 77,89 \\
7 & 0,83 & 5,17 & 83,06 \\
8 & 0,69 & 4,34 & 87,40 \\
9 & 0,59 & 3,69 & 91,09 \\
10 & 0,55 & 3,43 & 94,52 \\
11 & 0,42 & 2,61 & 97,13 \\
12 & 0,34 & 2,13 & 99,26 \\
13 & 0,08 & 0,50 & 99,76 \\
14 & 0,03 & 0,19 & 99,95 \\
15 & 0,01 & 0,03 & 99,98 \\
16 & 0,00 & 0,02 & 100,00 \\
\hline
\end{tabular}

Table 5. Factor Analysis Results

In order to determine the factors which the ratios belong to we use rotated component matrix given in Table 6 . In Table 6, the ratio with the highest score in a raw belongs to the corresponding factor labeled in the column. Accordingly, R14, R16, R15, R17 and R18 are classified within the factor 1. Similarly, R9, R7 and R26 are classified as factor 2, while R27, R12, R28 and R13 are concentrated in factor 3. Lastly, factor 4 is composed of R1, R6, R29 and R3. 


\begin{tabular}{lcccc}
\hline \multicolumn{4}{c}{ Components } \\
\hline R14 & $\mathbf{1}$ & $\mathbf{2}$ & $\mathbf{3}$ & $\mathbf{4}$ \\
R16 & 0,91 & 0,00 & 0,25 & $-0,16$ \\
R15 & 0,87 & $-0,02$ & 0,25 & $-0,14$ \\
R17 & 0,87 & $-0,01$ & 0,19 & $-0,25$ \\
R18 & 0,75 & 0,04 & $-0,25$ & 0,16 \\
R9 & 0,05 & 0,95 & $-0,30$ & 0,11 \\
R7 & 0,05 & 0,94 & 0,05 & $-0,10$ \\
R26 & $-0,08$ & 0,75 & 0,17 & $-0,12$ \\
R27 & $-0,14$ & 0,11 & 0,74 & 0,10 \\
R12 & 0,08 & 0,08 & 0,70 & 0,00 \\
R28 & 0,13 & $-0,02$ & 0,59 & 0,02 \\
R13 & 0,04 & 0,15 & 0,46 & 0,12 \\
R1 & 0,05 & 0,04 & 0,00 & $-0,35$ \\
R6 & 0,01 & 0,22 & 0,39 & 0,84 \\
R29 & $-0,31$ & $-0,31$ & $-0,09$ & 0,48 \\
R3 & 0,02 & $-0,34$ & $-0,37$ & 0,40 \\
\hline
\end{tabular}

Table 6. Rotated Component Matrix

In order to investigate the financial risk in Turkish bank system, as the last tool of ou empirical strategy, we utilize from Probit regression. In this regard, we estimate the following model;

$Y_{i}=\alpha+\beta_{1} X_{1}+\beta_{2} X_{2}+\beta_{3} X_{3}+\beta_{4} X_{4}$

where $Y_{i}$ is a dummy and boolean variable which equals 1 if the corresponding bank is failed. Besides, $X_{i}, i=$ 1,2,3,4 indicates factor scores calculated previously. The results of Probit regression can be found in Table 7. Table 7 indicates that factor 2 and factor 3 have statistically significant and negative impact on failure probability of the banks in Turkey. This finding does not change in the cases where missing values are replaced by mean and nearby points. Furthermore, factor 3 has relatively higher negative effect on the probability of failure in Turkey with the value of $-0,911$, relative to that of factor 2 . This finding is verified by the other two Probit model estimations where the effect of factor 3 are estimated as $-0,999$ and $-0,996$, respectively. On the other hand, given the methodology employed, in all of three regressions, we find no significant association for factor 1 and factor 4 on the probability of failure. Besides, the last significant parameter in all three models is intercept term.

\begin{tabular}{cccc|ccc|ccc}
\hline Variable & $\begin{array}{c}\text { With Missing Values } \\
\text { Estimate }\end{array}$ & $\begin{array}{c}\text { Std. } \\
\text { Error }\end{array}$ & Sig. & With Mean & Estimate & $\begin{array}{c}\text { Std. } \\
\text { Error }\end{array}$ & Sig. & With Nearby Points \\
Estimate & $\begin{array}{c}\text { Std. } \\
\text { Error }\end{array}$ & Sig. \\
\hline X1 & $-0,169$ & 0,114 & 0,140 & $-0,185$ & 0,108 & 0,085 & $-0,209$ & 0,110 & 0,058 \\
X2 & $-0,422$ & 0,074 & 0,000 & $-0,414$ & 0,071 & 0,000 & $-0,411$ & 0,071 & 0,000 \\
X3 & $-0,911$ & 0,135 & 0,000 & $-0,999$ & 0,127 & 0,000 & $-0,996$ & 0,126 & 0,000 \\
X4 & $-0,047$ & 0,115 & 0,680 & $-0,116$ & 0,100 & 0,245 & $-0,117$ & 0,100 & 0,241 \\
Const. & $-1,717$ & 0,122 & 0,000 & $-1,609$ & 0,110 & 0,000 & $-1,615$ & 0,110 & 0,000 \\
\hline
\end{tabular}

Table 7. Probit Regression Results

To evaluate whether the estimated Probit model fits the observed data, we use Chi-square test. In this test, null hypothesis asserts that the Probit model fitted is authentic. Under this null hypothesis, Chi-square test results confirm that null hypothesis cannot be rejected with the significance value of 1 .

Regarding the performance of the models estimated, we compare the forecasted probability of failure with previously failed banks. Failure probabilities for the respective models are presented in Table 8 for previously failed banks and in Table 9 for current banks. In Table 8, we attain a particular importance to the probability forecasted for one year earlier (t-1) from bankruptcy. Results in Table 8 show that we can obtain higher failure probabilities for some banks, while we observe relatively lower probabilities for other banks. The models estimated are especially successful in forecasting the bank failure probability of some banks such as Interbank, (97\%), Türkiye Tütüncüler Bankası-Yaşarbank A.Ş. (73\%), İktisat Bankası T.A.Ş. (85,5\%). The lower probabilities forecasted for previously failed banks are for Bayındırbank A.Ş. (8\%) and Türkiye İmar Bankası (15\%). 


\begin{tabular}{|c|c|c|c|c|c|}
\hline Bank & Year (t-1) & $\begin{array}{l}\text { Missing } \\
\text { Prob. }\end{array}$ & $\begin{array}{l}\text { Mean } \\
\text { Prob. }\end{array}$ & $\begin{array}{c}\text { Nearby Points } \\
\text { Prob. }\end{array}$ & $\begin{array}{c}\text { Average } \\
\text { Prob. }\end{array}$ \\
\hline Türk Ticaret Bankası A.Ş. & 1996 & NA & 0,084 & 0,298 & 0,191 \\
\hline Bank Ekspres A.Ş. $\quad * * *$ & 1997 & NA & 0,250 & 0,301 & 0,276 \\
\hline Interbank & 1998 & 0,958 & 0,992 & 0,963 & 0,971 \\
\hline Sümerbank A.Ş. & 1998 & 0,465 & 0,586 & 0,532 & 0,527 \\
\hline Türkiye Tütüncüler Bankası -Yaşarbank A.Ş. & 1998 & 0,613 & 0,908 & 0,688 & 0,736 \\
\hline Yurt Ticaret ve Kredi Bankası A.Ş. & 1998 & 0,358 & 0,477 & 0,467 & 0,434 \\
\hline Egebank A.Ş. & 1998 & 0,183 & 0,383 & 0,217 & 0,261 \\
\hline Eskişehir Bankası T.A.Ş. & 1998 & 0,454 & 0,761 & 0,500 & 0,572 \\
\hline Bank Kapital Türk A.Ş. & 1999 & 0,125 & 0,161 & 0,166 & 0,151 \\
\hline Etibank A.Ş. & 1999 & 0,270 & 0,343 & 0,343 & 0,319 \\
\hline Demirbank T.A.Ş. & 1999 & 0,119 & 0,168 & 0,148 & 0,145 \\
\hline Ulusal Bank T.A.Ş. & 2000 & 0,669 & 0,596 & 0,764 & 0,676 \\
\hline İktisat Bankası T.A.Ş. & 2000 & 0,834 & 0,876 & 0,854 & 0,855 \\
\hline Bayındırbank A.Ş. & 2000 & 0,075 & 0,082 & 0,084 & 0,080 \\
\hline Ege Giyim Sanayicileri Bankası A.Ş. & 2000 & 0,412 & 0,387 & 0,491 & 0,430 \\
\hline Kentbank A.Ş. & 2000 & 0,154 & 0,178 & 0,202 & 0,178 \\
\hline Sitebank A.Ş. & 2000 & 0,358 & 0,365 & 0,416 & 0,379 \\
\hline Milli Aydın Bankası T.A.Ş. & 2000 & 0,332 & 0,316 & 0,374 & 0,341 \\
\hline Türkiye Emlak Bankası A.Ş. & 2000 & 0,335 & 0,475 & 0,371 & 0,394 \\
\hline Toprakbank A.Ş. & 2000 & 0,253 & 0,341 & 0,290 & 0,295 \\
\hline Pamukbank T.A.Ş. $\quad * * *$ & 2001 & 0,161 & 0,225 & 0,216 & 0,201 \\
\hline Türkiye İmar Bankası T.A.Ş. & 2002 & 0,105 & 0,219 & 0,151 & 0,158 \\
\hline
\end{tabular}

Table 8. Probabilities for Previously Failed Banks

Considering the failure probability of the current Turkish banks, we observe from Table 9 that the maximum failure probability is $10,8 \%$ for B9. When we compare with the Table 8 , we may conclude that these probabilities do not support a possible bankruptcy for current Turkish banks. Besides, our findings imply that all of publiclyowned banks are sound against bankruptcy, with probabilities quite close to zero. Furthermore, we find that 4 of 13 foreign-owned banks are placed as the least risky banks. In addition to that, the major privately owned banks show a robust stance against bankruptcy

\begin{tabular}{lllcl}
\hline Bank Codes & Missing & Mean & Nearby Point & Average \\
\hline B21 & 0,001 & 0,000 & 0,001 & 0,001 \\
B26 & 0,002 & 0,000 & 0,001 & 0,001 \\
B16 & 0,002 & 0,001 & 0,002 & 0,001 \\
B1 & 0,004 & 0,001 & 0,004 & 0,003 \\
B13 & 0,006 & 0,002 & 0,006 & 0,004 \\
B12 & 0,006 & 0,002 & 0,006 & 0,005 \\
B2 & 0,007 & 0,003 & 0,008 & 0,006 \\
B17 & 0,008 & 0,003 & 0,009 & 0,007 \\
B5 & 0,008 & 0,006 & 0,009 & 0,008 \\
B19 & 0,011 & 0,003 & 0,014 & 0,009 \\
B3 & 0,012 & 0,010 & 0,014 & 0,012 \\
B14 & 0,015 & 0,015 & 0,019 & 0,016 \\
B4 & 0,029 & 0,013 & 0,028 & 0,023 \\
B11 & 0,024 & 0,022 & 0,033 & 0,026 \\
B23 & 0,028 & 0,028 & 0,037 & 0,031 \\
B27 & 0,033 & 0,043 & 0,047 & 0,041 \\
B22 & 0,032 & 0,048 & 0,045 & 0,042 \\
B20 & 0,041 & 0,052 & 0,056 & 0,050 \\
B6 & 0,038 & 0,082 & 0,054 & 0,058 \\
B18 & 0,052 & 0,073 & 0,078 & 0,068 \\
B15 & 0,052 & 0,098 & 0,080 & 0,076 \\
B25 & 0,060 & 0,079 & 0,093 & 0,077 \\
B8 & 0,057 & 0,101 & 0,082 & 0,080 \\
B7 & 0,059 & 0,099 & 0,092 & 0,084 \\
B24 & 0,070 & 0,116 & 0,108 & 0,098 \\
B10 & 0,075 & 0,114 & 0,110 & 0,100 \\
B9 & 0,081 & 0,120 & 0,124 & 0,108 \\
\hline
\end{tabular}

Table 9. Probabilities for Current Banks 


\section{Conclusion}

In this study we investigate the failure probability for current deposit Turkish banks using data extracted from Banking Regulation and Supervision Agency for the period 1996-2014. To this end, we utilize from an analysis composed of three stages, namely, ANOVA test, Factor Analysis and Probit Regression Analysis. Having faced with 55 missing data in the original data set, we perform our analysis depending on different missing value replacement approaches, namely replacing with mean and nearby points.

Our principal findings show that the models estimated can be considered successful in terms of forecasting previously failed banks. These results do not change in the cases where missing data problem is eliminated with different approaches. Regarding the failure probabilities of the current banks, we find that there is no any risk of bankruptcy since the failure probabilities are far from the ones predicted for previously failed banks. Therefore, our main conclusion regarding the financial risk in Turkish banking system is that all of the current deposit banks are found to be robust and sound against failure risks. These findings may be interpreted as a result of the economic recovery program launched in 2001 which aimed to regulate baking system in Turkey.

\section{Acknowledgements}

I would like to thank Cukurova Univercity Scientific Research Projects (Project Id: 6550) that helped us to present this study in International Conference on Eurasian Economies, Kaposvar-Hungary.

\section{References}

- Canbaş S., and Erol, C. 1985. “Türkiye’de Ticaret Bankaları Sorunlarının Saptanması: Erken Uyarı Sistemine Giriş", Türkiye Ekonomisi ve Türk Ekonomi Ilmi, No: 1, Marmara University, Turkey Economy Research Center.

- Canbaş, S., Çabuk, A. and Kiliç, S.B. 2005. "Prediction of commercial bank failure via multivariate statistical analysis of financial structures: The Turkish case”, European Journal of Operational Research, 166 (2), 52846

- Caprio, G. and Klingebiel, D. .2002. "Episodes of Systematic and Borderline Banking Crises", World Bank Discussion Papers, No.428, 31-49.

- Claessens, S., D. Klingebiel, and L. Laeven. 2005., "Crisis Resolution, Policies, and Institutions: Empirical Evidence," in Patrick Honohan and Luc Laeven, Systemic Financial Crises: Containment and Resolution (Cambridge University Press).

- Chen, M., Chew M. L., Goyal, S., Matar, M. and Yavuz, Z. 2014. "The Turkish Economy, Post-2001 Crisis: Why Timing, Faith, and Expectations Matter”, UChicago Undergraduate Business Journal, Spring,1-34.

- Contessi, S., and El-Ghazaly, H. S. 2011. Banking crises around the world: different governments, different responses. The Regional Economist, (Apr), 10-16.

- De Claro, L. L., 2013. "Determining The Effectiveness of The Camels Approach Towards Timely Prediction of Bank Failures", Journal of Global Business And Economics, January, VolumE 6, Number 1, 12-17.

- Ecer, F. 2013. "Comparing the bank failure prediction performance of neural networks and support vector machines: The Turkish case, Ekonomska istraživanja - Economic Research 26(3):81-98.

- Erdoğmuş, B. 2010. "Bankalarda Mali Başarısızlıkların Önceden Tespitinde Erken Uyarı Sistemi ve Bir Uygulama”, Ankara Üniversitesi Fen Bilimleri Enstitüsü, YL Tezi.

- Fethi, M. D. and Pasiouras, F. 2010. "Assessing bank efficiency and performance with operational research and artificial intelligence techniques: A survey”, European Journal of Operational Research, 204 (2), 189198.

- Fungacova, Z. and Weill, L. 2013. "Does competition influence bank failures? Evidence from Russia", Economics of Transition, Volume 21(2) 2013, 301-322. DOI: 10.1111/ecot.12013

- Honohan, P. and Klingebie, D. 2003. "The fiscal cost implications of an accommodating approach to banking crises", Journal of Banking \& Finance, Vol.27, Issue.8, 1539-1560.

- Kyle, A. S. 2012. “A commentary on "Déjà Vu All Over Again: The Causes of U.S. Commercial Bank Failures This Time Around”, J Finance Serv Res . 42: 31-34.

- Liu, Z.J. 2014. "Cross-country study on the determinants of bank financial distress”, RAEI São Paulo, V. 55 , n. 5 , 593-603. DOI: http://dx.doi.0rg/1O.1590/S0034-75902015051O

- Lopcu, and K., Kiliç, S.B. 2012. "Effects of Structural Changes in the Turkish Banking Sector Since 2001 Crisis and a Risk Analysis for the Sector", Topics in Middle Eastern and North African Economies, Vol. 14,September, 354-376.

- Papi, L., Presbitero, A. F. and Zazzaro, A. "IMF Lending and Banking Crises", https://www.imf.org/external/pubs/ft/wp/2015/wp1519.pdf 20.5.2016

- Reinhart, Carmen M. and Rogoff, Kenneth S.(2011), ""From Financial Crash to Debt Crisis," American Economic Review, American Economic Association, vol. 101(5), 1676-1706. 